\title{
Social Support for Adolescent Resilience in Dealing With Conflicts in Divorced Parents
}

\author{
Muhadir Muhammad1, Herman Nirwana', Marjohan ${ }^{1}$ \\ 1Universitas Negeri Padang \\ *Corresponding author, e-mail: muhadirkonselor@gmail.com
}

\begin{abstract}
This research aims to determine social support for adolescent resilience in dealing with conflict in divorced parental environments that includes phase dimensions, and resilience strategies. This article is based on research using a qualitative method of case study type. Research subjects numbered 3 teenagers with the criteria of having divorced parents alive. Data collection techniques used in the form of in-depth interviews and observation. The data analysis technique used by researchers is guided by the Miles \& Huberman model. The results of the analysis of research data indicate that the resilience phase that is passed by adolescents whose parents divorced live differently from each other. This is influenced by social support factors obtained by adolescents in facing life's challenges. The different phases through which each subject will also distinguish the resilience strategies used by each subject to survive in the face of conflict in the environment of divorced parents.
\end{abstract}

Keywords: Social Support, resilience, Divorced,Adolescent

\section{Introduction}

Values-cultural and religious values play an important role in regulating the life of the family, the family is seen as a residence and shelter, in the shade of a family body and soul meet with based on love, compassion, cover shortages, beauty and purity. Two-way communication under democratic conditions will occur in whole families, children live growing and developing into adolescents and adults, from the eternal family the integration of affection and responsibility (Willis, 2009).

The phenomenon of a divorced family isrife among the people, especially the people of Padang City, where there are quite a lot of divorces and ironically the divorce cases in this city have increased significantly each year, this was revealed in the data collection that researchers conducted at the Religious Court IA class Padang, can be explained as follows: in 2015 there were 1513 divorce cases, in 2016 there were as many as 1577 divorce cases and in 2017 there were 1805 divorce cases.

Based on the data that has been explained before, it can be seen that the number of divorces in the city of Padang is very large and increases significantly every year, if divided 
per day there are four people who become widows and widowers every day. The increasing number of divorce would have a broad impact on the family itself, including the number of children and adolescents who are victims of divorce will increasingly builds up $t$ annually in line with the increase in the divorce rate, so very concerned about teenagers who are victims of parents' divorce will face new problems such as sadness, lack of get attention, juvenile delinquency, fear, depression and other misconduct.

The life that an individual lives is full of low levels of stress on a daily basis, and sometimes dealing with more serious stresses, such as earthquakes, floods and family problems in dealing with these stresses, there are individuals who can deal with it, but sometimes also not a few individuals which cannot overcome it, causing problems for individuals(Nirwana, 2012).Divorce will also lead to the separation of children from their parents, so the child will be separated from one of his parents.Jane (2011) explains that during divorce parents give an emotional reaction which is common in children of all ages, including sadness, fear, depression, anger and confusion .

Harvey \& Fine (Santrock, 2007)explained that most researchers agreed that children and adolescents who came from divorced families showed worse adjustments than their peers from intact families. Adolescents who come from families with divorce from their parents show academic problems, externalizing problems such as juvenile delinquency, and internalization problems such as anxiety and depression, lack of social responsibility, dropping out of school, sexually active at an early age, taking illegal drugs. , join with friends who are anti-social and have low self-esteem.

Ifdil,\& Taufik, (2012) explained that individuals in dealing with various problems that occur require the ability to be able to adapt to these conditions which can increase their potential after facing a stressful situation. That ability is what is meant by resilience. The above statement is supported by the results of Mcgillivray \& Pidgeon (2015) research showing that resilience is one of the key factors in reducing individual psychological distress. In this study it was reported that adolescents or individuals who are at a high level of resilience have low scores on the psychological stress variable.

Etymologically the word resilience comes from the Latin " resilire' ' (spring return) which means a capacity to recover or bounce back from the deterioration faced so that it will return to an effective life Masten, \& Gerwitz, (2006). Resilience is the ability to overcome and adapt to severe events or problems encountered in life, survive in a state of stress and even deal with misery or trauma experienced in his life Reivich, \& Shatte, (2002).

Patterson, Kelleher, \& Abbott, (2005) explained that there are four phases of resilience that may occur in individuals when there are difficulties in their lives: (1) deteriorating, is a phase when difficulties arise generally individuals will experience the worst conditions which are also the initial phase of resilience. (2) adapting, this phase is a transition phase where individuals begin to get used to the difficult situations they face (3) recovering, in this phase individuals are in the status quo, neutral. (4) growing, the last phase of resilience in which individuals grow stronger than lessons learned from the experiences faced when difficulties hit. With the difficulties that arise individuals learn how to deal with and solve these problems.Patterson et al., (2005) explain that adolescents' ability to survive is influenced by resilience strategies. Resilience strategies are a number of ways in which adolescents retain resilience to maintain survival in the midst of stressful conditions.

Patterson \& Kelleher, (2005)mentioned that there are seven key strengths used by adolescents in maintaining their resilience, namely optimism in facing life, focusing on core 
values, being flexible in trying to achieve goals, daring to take concrete steps in facing difficulties, creating self-conditions and supportive environment, maintain high expectations and expectations, and develop participatory attitudes and responsibilities.Everall, Altrows, \& Paulson, (2006) explain that social competencies possessed by individuals. Greatly affects adolescent resilience such as family factors, including support that comes from parents, in addition to support from parents the family structure also plays an important role for individuals. community factors, including poverty and limited employment opportunities.

Conditions and phenomena described above Installing the constellation researchers to examine the resilience of youth in the face of conflict in divorced parents living environment that includes dimensions, phases through which resilience, and resilience are used to maintain resilience strategy.

\section{Method}

This article is based on research using qualitative methods with the type of case study. The case in this case means a special phenomenon that is present in a limited context( bounded context). The research was conducted at the Islamic Middle School Khaira Ummah Padang. The subjects in this research were three teenage students with the criteria of having divorced parents living in a period of less than three months. The data collection techniques of this study were in-depth interviews and observations. The technique guarantees the validity of the data, namely: (1) extending the time for researchers to participate in the field (2) increase the perseverance of observation (3) triangulate (4) using appropriate reference material. The data analysis technique used by researchers is guided by the Miles \& Huberman model.

\section{Results and Discussion}

The results of this research prove that only subject I has good social support from his extended family, so he can face problems in his family optimistically and take concrete steps in dealing with difficulties. Subject I views that all difficulties he faces are challenges that must be dealt wisely, subjects who have good social support in life make these challenges a motivation to struggle and provide hope for change for the better in their family environment. This is corroborated by Patterson \& Kelleher, (2005)who explain that one of the factors that affect resilience is to create a favorable self and environmental conditions. Furthermore Setianingsih, Uyun, \& Susatyo, (2010)explained that the social environment has a very big influence on the lives of adolescents, because adolescents no longer only interact with family at home or with friends at school but also begin to establish relationships with people adults outside the home and school environment, that is the community environment. Environmental conditions change all the time, therefore teenagers are required to be able to foster and adapt to new forms of relationships in various situations. Wahid, Larasati, Ayuni, \& Nashori, (2018) explained that good social support from the environment will stimulate an attitude of individual optimism, and an optimistic attitude will positively influence the quality of life and problem solving of adolescents.

While subjects II and III have the same pattern of support, they do not get the attention and affection from their extended family, so that it affects the pessimistic outlook, they see that they will not be able to deal with conflicts within their family, because they try to be unrealistic in seeing the condition of their family which is very chaotic. In line with this 
Howard \& Johnson (2004) in his research explained that individuals who have negative views do not have progress in dealing with problems that arise. Kurniati \& Fakhruddin, (2018)explained that pessimistic individuals become one of the scale of attitudes that can influence the view of the future, and can change the individual's perspective on the problems faced. Pessimistic attitudes of individuals tend to be negative, giving the impact of weak fighting power, and the end result in the form of failure. Hidayat, (2017) explained to help individuals in dealing with problems need support from the family so that individuals will avoid pessimism.

Research data shows that all subjects followed their duties as teenagers in their respective families, subject I had self-confidence in dealing with family conflicts, because of the motivation and support from his family. While subjects II and III show the lack of confidence in dealing with conflicts within the family due to divorced parents. they feel inferior, very depressed and feel insecure. Because subjects I and II do not have good social support from extended family.

Some concrete actions carried out by the subjects are almost the same, namely persisting in a conflicting family environment even with different feelings, namely subject I feeling optimistic and confident to face conflict in his family, because of the affection, attention and encouragement from his extended family, whereas subjects II and III felt pessimistic and felt insecure because of the very weak attention and motivation of the extended family.In this research, not all subjects experienced the entire resilience phase above. Only subject I experienced the four phases, this happened because subject I had an optimistic outlook on life that made it easier to face challenges and rise from the deteriorating phase, in addition, project I had very good support from the family environment compared to the other two subjects.

Subject II was only able to arrive at the adapting phase. A pessimistic view of life makes it difficult for subject II to rise from adversity, because he feels unable to deal with conflicts within his family, also because of support from a very weak family environment, even though over time subject II can begin to deal with conflicts within his family. Meanwhile the research data shows that subject III is still deteriorating, besides the conflict conditions in his family subject III does not have good motivation from his family. In line with this Siegel \& Welsh, (2011) explained that family, school, and game friends are considered to be factors that influence an individual's ability to deal with life problems, social support from parents is a major cause of teenagers' success or failure in dealing with problems in life. Nindya \& Margareta, (2012) explained that parents who ignore and ignore teenagers tend to cause problems for adolescents so that individuals cannot face life problems.

This research shows that subjects who have good social support will give birth to an optimistic view of life will tend to be easier to get through difficult times and support from families to get up to a better phase. While individuals who do not have affection, support and motivation from the family will give birth to pessimism in life tends to be trapped in difficult conditions and unable to get through it. This analysis is in line with the opinion of Reivich, \& Shatte, 2002)that resilient individuals are optimistic individuals. This individual believes that something that he found can change for the better, optimism will be very useful for individuals when accompanied by self-efficacy, with optimism that individuals are constantly encouraged to find solutions to problems and continue to work hard for more conditions well, of course the optimism in question is realistic optimism . Kurniati \& 
Fakhruddin, (2018) explained that optimism and pessimism become one of the scale of attitude that can influence the view of the future, and can change the way of individual view of the problems faced. The attitude of optimism possessed by individuals tends to have a positive impact on motivation, fighting power, and final results in the form of achievement.

Meanwhile the resilience strategies that emerge in each subject tend not to be the same. Subject I who has good support from the environment in life gave rise to seven resilience strategies used in dealing with difficult conditions. Meanwhile subject II, which did not have good social support from the environment, gave birth to a pessimistic view which only led to two resilience strategies. While Subject III, who also did not have good social support from the environment, was not able to come up with any strategy in surviving to deal with family conflicts. These points appear in the behavior of the three subjects in daily life, both conscious and unconscious, which indirectly actually help them survive in difficult conditions in dealing with situations of family conflict. This is corroborated by research by Patterson, Loucrecia, \& Abbott, (2004)which states that resilience strategies emerge influenced by optimistic levels of life and phaseresiliency experienced by individuals.

\section{Conclusion}

Adolescent resilience appears from the four phases, which are heteriorating, adapting, recovering, and growing. This research shows that not all adolescents are able to pass through these four phases. The ability of adolescents to pass fasciencilence is influenced by the resilience dimension. The interpretation dimension that is reflected in the adolescent's life perspective is an important factor that gives a positive influence in the resilience of melatiatifase because teenage interpretation on life will be the basis for them to respond to a problem. rise to a better phase. While teenagers who do not have good social support will give birth to pessimism, so that life tends to be trapped in difficult conditions and unable to pass through it. The strategy that emerged in this study consisted of the ability to create self and environmental conditions that support adolescents in facing difficult situations.

\section{References}

Everall, R. D., Altrows, K. J., \& Paulson, B. L. (2006). Creating a future: a study of resiliences in suicidal female adolescents. Jurnal of Counseling \& Development, 83(4). 230-242.

Hidayat A. (2017). Konsep diri dan kecemasan mahasiswa dalam pemecahan masalah matematika bisnis ditinjau dari perbedaan gaya kognitif field dependent dan field independent. Jurnal Gammath,2(1). 55-64

Howard, S., \& Johnson, B. (2004). Resilient Teachers: Resisting Stress and Burnout. Social Psychology of Education, 7(4), 399-420.

Ifdil., \& Taufik. (2012). Urgensi peningkatan dan pengembangan resiliensi siswa di sumatera barat. Jurnal Ilmu Pendidikan. 12 (2), 115-121.

Jane, B. (n.d.). The process of parenting. New York: McGraw-Hill.

Kurniati, L., \& Fakhruddin, A. U. (2018). Pengaruh optimisme terhadap kemampuan pemecahan masalah matematika pada siswa SMA. Prosiding Seminar Nasional $\mathcal{E}$ Internasional, 1(1). 115-120.

Masten, A. S., \& Gerwitz, A. H. (2006). Resilience in development, the importance of early 
childhood. encyclopedia on early childhood development. USA: University Of Minessota.

Mcgillivray, C. J., \& Pidgeon, A. M. (2015). Resilience attributes among university students: a comparative study ofpsychological distress, sleep disturbances and mindfulness.European Scientific Journal.(ESJ) 11(5), 33-48.

Nindya, PN., \&Margareta, R (2012). Hubungan antara kekerasan emosional pada anak terhadap kecenderungan kenakalan remaja. Jurnal Psikologi Klinis Dan Kesehatan Mental, 1(2).124-132

Nirwana, H. (2012). Konseling trauma pasca bencana. Jurnal Ta'dib 15(2), 123-128.

Patterson, J. H., Loucrecia, C., \& Abbott, G. (2004). A study of teacher resilience in urban school. Journal of Instructional Psychology, 31(1), 3-11.

Patterson, J. L., \& Kelleher, P. (2005). Resilient school leaders: stategies for turning adversity into achievement. Alexandria: Association for Supervission and Curriculum Develompent (ASCD).

Reivich, K., \& Shatte, A. (2002). The resilience factor: 7 essential skills for overcoming life's inevitable obstacles. NEW YORK: Broadway Books.

Santrock, J. W. (2007). Child depelovment. New York:McGraw-Hil.

Setianingsih, E., Uyun, Z., \& Susatyo, Z. (2010). hubungan antara penyesuaian sosial dan kemampuan menyelesaikan masalah dengan kecenderungan perilaku delinkuen pada remaja. Jurnal Psikologi, 3(1). 29-35

Siegel, J., \& Welsh, B. (2011). Juvenile Delinquency The Core. California: Wadsworth.

Wahid, A., Larasati, A., Ayuni, \& Nashori, F. (2018). optimisme remaja yang tinggal di panti asuhan ditinjau dari kebersyukuran dan konsep diri humanitas. Humanitas, 15(2). 123130.

Willis, S. S. (2009). Konseling keluarga (Family counseling). Bandung: Alfabeta. 